\title{
Effect of Insecticide Seed Treatment on Safening Rice from Reduced Rates of Glyphosate and Imazethapyr
}

\author{
M. R. Miller, ${ }^{1}$ R. C. Scott, ${ }^{2}$ G. Lorenz, ${ }^{3}$ J. Hardke, ${ }^{4}$ and J. K. Norsworthy ${ }^{1}$ \\ ${ }^{1}$ Department of Crop, Soil, and Environmental Sciences, University of Arkansas, Fayetteville, AR 72701, USA \\ ${ }^{2}$ Department of Crop, Soil, and Environmental Sciences, Lonoke Extension Center, University of Arkansas, Lonoke, AR 72086, USA \\ ${ }^{3}$ Department of Entomology, Lonoke Extension Center, University of Arkansas, Lonoke, AR 72086, USA \\ ${ }^{4}$ Department of Crop, Soil, and Environmental Sciences, Rice Research and Extension Center, University of Arkansas, \\ Stuttgart, AR 72160, USA
}

Correspondence should be addressed to M. R. Miller; mrm032@uark.edu

Received 8 April 2016; Accepted 22 June 2016

Academic Editor: David Clay

Copyright (C) 2016 M. R. Miller et al. This is an open access article distributed under the Creative Commons Attribution License, which permits unrestricted use, distribution, and reproduction in any medium, provided the original work is properly cited.

Field experiments were conducted in 2013 and 2014 to evaluate the effect of insecticide seed treatments on exposure of young conventional rice to reduced rates of glyphosate and imazethapyr. During the two-year study, "Roy J" rice seed was treated with CruiserMaxx ${ }^{\circledR}$ Rice, thiamethoxam plus fungicide, or a fungicide-only treatment. Subsequently, glyphosate (Roundup PowerMax ${ }^{\circledR}$ ) at 39.42, 78.76, or $157.54 \mathrm{~g}$ ae/ha or imazethapyr $\left(\right.$ Newpath $\left.^{\circledR}\right)$ at $4.39,8.74$, or $17.49 \mathrm{~g}$ ai/ha was applied at the 2- to 3-leaf growth stage of rice. Results in 2013 indicated that rice plants from seed treated with CruiserMaxx Rice exhibited significantly less injury 1, 3, and 6 weeks after either imazethapyr or glyphosate was applied in comparison to the plants having fungicide-only treated seed. The addition of an insecticide seed treatment also resulted in higher yields when both herbicides were applied compared to the fungicide-only seed treatment receiving the same herbicide treatments. In 2014, an overall decrease in injury from both herbicides was observed when rice seed was treated with CruiserMaxx Rice compared to receiving a fungicide-only seed treatment. Significant yield loss from low rates of glyphosate or imazethapyr was not observed in 2014, with or without a seed treatment. Based on the positive effects observed from the CruiserMaxx Rice seed treatment in reducing injury and maintaining rice yields, the insecticide seed treatment appears to provide some safening to rice against low rates of glyphosate and imazethapyr.

\section{Introduction}

In 2014, Arkansas led the nation in rice production with approximately $50 \%$ of the rice acreage planted [1]. Of the Arkansas rice acreage, an estimated 49\% was planted to nontransgenic, imidazolinone-resistant rice cultivars (Clearfield ${ }^{\circledR}$, BASF, Research Triangle Park, NC) [2]. Typically, acreage planted with the Clearfield rice technology will receive multiple applications of acetolactate synthaseinhibiting (ALS) herbicides for weed control such as Newpath (imazethapyr, BASF, Research Triangle Park, NC), Beyond ${ }^{\circledR}$ (imazamox, BASF, Research Triangle Park, NC) [3, 4], or Clearpath ${ }^{\circledR}$ (imazethapyr + quinclorac, BASF, Research Triangle Park). Consequently, the rice acreage remaining is planted to rice cultivars which do not contain the imidazolinone resistance trait and cannot therefore tolerate applications of imazethapyr or imazamox. In other words, non-Clearfield rice acreage is susceptible to injury should imazethapyr or imazamox be applied to the field through tank-contamination, drift, or accidental application.

In addition to rice, Arkansas consistently produces around 1.4 million of hectares of soybean and corn with a majority of acreage planted to glyphosate-resistant varieties (Roundup Ready ${ }^{\circledR}$, Monsanto, St. Louis, MO) [1]. The widespread adoption of this technology has resulted in a tremendous amount of reliance on glyphosate (Roundup ${ }^{\circledR}$, Monsanto, St. Louis, MO) for weed control in these production systems. Moreover, it is not uncommon for corn and soybean fields to be located nearby or adjacent to areas where rice is grown therefore indicating that the potential for rice exposure to glyphosate through tank-contamination and/or drift exists. 
Previous research has shown reduced yields when rice was exposed to imazethapyr and glyphosate, depending on rate and timing of exposure $[5,6]$. In a subsequent study, Hensley et al. [7] reported that simulated glyphosate drift resulted in rice injury, reduced canopy height, and decreased yield when compared to the nontreated glyphosate drift. One potential option to safen conventional rice from accidental exposure to such herbicides could be through the use of insecticide seed treatments. In recent years, the use of insecticide seed treatments has increased significantly with a large adoption percentage in corn and soybean [8]. While insecticide seed treatments provide additional crop benefits by decreasing insect pressure thus improving yields, they have also been observed to alter crop tolerance to herbicide applications [9-12]. The ability to safen rice from unwanted exposure to herbicides could be a valuable tool for rice producers especially in areas such as Arkansas where rice is commonly grown in combination with other row crops containing differing herbicide resistance traits.

In 2011, Gus Lorenz, University of Arkansas Extension Entomologist, observed that some of his rice plots which had been previously treated with an insecticide seed treatment were better able to tolerate an accidental herbicide drift event from an adjacent field compared to plots which had not received the seed treatment. If found to be effective, the use of insecticide seed treatments could not only provide the expected insect control but also prevent unwanted injury from low doses of herbicides. Therefore, it was hypothesized that an insecticide seed treatment in rice would be able to provide some safening effect from low doses of herbicides. The objective of this research was to evaluate the potential of an insecticide seed treatment to safen conventional rice from simulated drift rates of glyphosate and imazethapyr.

\section{Materials and Methods}

A field experiment was conducted at the University of Arkansas Pine Bluff Research Farm in Lonoke, AR, in 2013 and repeated in 2014. Plots measured $6 \mathrm{ft}$ in width by $25 \mathrm{ft}$ in length and were established on a mix of Calhoun silt loam (fine-silty, mixed, active, thermic Typic Glossaqualfs) and Immanuel silt loam (fine-silty, mixed, active, thermic Oxyaquic Glossudalfs) with a $\mathrm{pH}$ of 6.3. In both years, conventional "Roy J" rice seed was planted at $100 \mathrm{~kg} / \mathrm{ha}$ (approximately $7 \mathrm{seeds} / \mathrm{m}$ of row) on $19 \mathrm{~cm}$ wide rows with planting occurring on April 13, 2013, and May 20, 2014. The experimental design consisted of a randomized complete block with four replications and a two-factor factorial treatment structure. The first factor consisted of rice seed treatments, which are commonly applied to rice to provide an additional layer of protection from insects and diseases and tend to improve rice stand count and vigor. The rice seed was either treated with CruiserMaxx Rice (26.4\% thiamethoxam, $1.65 \%$ mefenoxam, $1.32 \%$ azoxystrobin, and $0.28 \%$ fludioxonil) at $198 \mathrm{~g} / 45 \mathrm{~kg}$ of rice seed or treated with equivalent amounts of mefenoxam, azoxystrobin, and fludioxonil without the addition of the insecticide thiamethoxam. The second factor consisted of herbicide treatment and included either glyphosate (Roundup PowerMax, Monsanto, St. Louis,
MO) applied at $39.42,78.76$, or $157.54 \mathrm{~g}$ ae/ha or imazethapyr (Newpath) applied at $4.39,8.74$, or $17.49 \mathrm{~g}$ ai/ha. A nontreated check was also included. All herbicides were applied using a $\mathrm{CO}_{2}$-pressurized backpack sprayer calibrated to deliver $94 \mathrm{~L} \mathrm{ha}$ at $40 \mathrm{PSI}$ at the 2- to 3-leaf growth stage of rice. Plots were kept weed-free using conventional rice herbicides beginning with a preemergence application of clomazone followed by propanil early postemergence and a preflood application of cyhalofop plus penoxsulam. Standard rice production practices typical for the region were used, nitrogen fertilizer in the form of urea was applied immediately prior to establishing the permanent flood, and the flood was maintained until the rice was ready to harvest. Visible injury to rice was rated 1,3 , and 6 weeks after the herbicide treatment (WAT) based on a scale of 0 to $100 \%$, relative to the nontreated control, with $0 \%$ representing no injury and $100 \%$ representing complete death. Rice canopy heights were measured 14 WAT by determining the average of three heights measured within each plot as described by Davis et al. [5]. Percent of rice heading was also measured 14 WAT on a scale of 0 to $100 \%$ heading, with $0 \%$ representing no rice heading and $100 \%$ representing the entire plot reaching the complete heading stage of rice. Yield was collected at harvest and adjusted for moisture. Data were subjected to ANOVA using the MIXED procedure in JMP (JMP Pro 12, SAS Institute Inc. Cary, NC). Where the ANOVA indicated significance, means were separated using Fisher's protected LSD $(\alpha=0.05)$.

\section{Results and Discussion}

Significant differences between years were observed for the parameters evaluated; therefore, years were analyzed separately. In 2013, the interaction between seed treatment and herbicide application was not significant for rice injury but main effects were significant. However, the interaction was significant for rice height, percent of heading, and yield. In 2014, neither the interaction nor either of the main effects was significant for rice injury, rice height, percent of heading, or yield. Therefore, there was no formal attempt to separate treatment means but rather standard errors of the mean are presented.

In both years, rice injury from herbicide applications was displayed as stunting and chlorosis. In 2013, 1 WAT, both glyphosate and imazethapyr caused visible injury to the rice plants from the fungicide-only treatment exhibiting $24 \%$ injury and significantly less injury (14\% injury observed) when the rice was treated with the thiamethoxam-containing insecticide seed treatment (Table 1). As reported by previous insecticide/herbicide interactions [9], an overall safening effect was observed with less visible injury occurring 1 WAT in 2013 in plots containing the insecticide seed treatment compared to those without an insecticide seed treatment. At the 3- and 6-WAT observations in 2013, rice having an insecticide seed treatment displayed less injury following applications of glyphosate or imazethapyr compared to the plants having no insecticide seed treatment. Although formal statistics could not be applied to the 2014 data, similar results were observed with overall less injury to plants that received an insecticide seed treatment compared to those that did 
TABLE 1: Impact of insecticide seed treatment on rice injury 1, 3, and 6 weeks after treatment averaged over reduced rates of imazethapyr (Newpath) and glyphosate (Roundup PowerMax) in 2013 and 2014.

\begin{tabular}{|c|c|c|c|c|c|c|c|c|c|c|c|c|}
\hline \multirow{4}{*}{ Treatments } & \multicolumn{12}{|c|}{ Rice injury $^{\mathrm{a}}$} \\
\hline & \multicolumn{6}{|c|}{2013} & \multicolumn{6}{|c|}{2014} \\
\hline & \multirow{2}{*}{\multicolumn{2}{|c|}{$1 \mathrm{WAT}$}} & & & \multicolumn{2}{|c|}{$6 \mathrm{WAT}$} & \multicolumn{2}{|c|}{$1 \mathrm{WAT}$} & \multicolumn{2}{|c|}{3 WAT } & \multicolumn{2}{|c|}{6 WAT } \\
\hline & & & \multicolumn{2}{|c|}{$\%$} & & & \multirow{2}{*}{$\frac{\%}{20}$} & \multirow{2}{*}{$\frac{\mathrm{SE}^{\mathrm{b}}}{3}$} & \multirow{2}{*}{$\begin{array}{c}\% \\
13\end{array}$} & \multirow{2}{*}{$\begin{array}{c}\mathrm{SE} \\
3\end{array}$} & \multirow{2}{*}{$\frac{\%}{2}$} & SE \\
\hline Nontreated $^{c}$ & 24 & $a^{a}$ & 37 & $\mathrm{a}$ & 44 & a & & & & & & 1 \\
\hline Treated & 14 & $\mathrm{~b}$ & 25 & B & 11 & $\mathrm{~b}$ & 5 & 2 & 9 & 2 & 1 & 0 \\
\hline
\end{tabular}

TABLE 2: Main effect of herbicide treatment on rice injury 1, 3, and 6 weeks after treatment (WAT) in 2013 and 2014.

\begin{tabular}{|c|c|c|c|c|c|c|c|c|c|c|c|c|c|}
\hline \multirow{4}{*}{ Treatments } & \multirow{4}{*}{$\begin{array}{c}\text { Rate } \\
\mathrm{g} \text { ai/ha }\end{array}$} & \multicolumn{12}{|c|}{ Rice injury $^{a}$} \\
\hline & & \multicolumn{6}{|c|}{2013} & \multicolumn{6}{|c|}{2014} \\
\hline & & \multicolumn{2}{|c|}{$1 \mathrm{WAT}$} & \multicolumn{2}{|c|}{3 WAT } & \multicolumn{2}{|c|}{6 WAT } & \multicolumn{2}{|c|}{$1 \mathrm{WAT}$} & \multicolumn{2}{|c|}{3 WAT } & \multicolumn{2}{|c|}{6 WAT } \\
\hline & & & & & & & & $\%$ & $\mathrm{SE}^{\mathrm{b}}$ & $\%$ & SE & $\%$ & SE \\
\hline Glyphosate $^{c}$ & 39.42 & 9 & $c^{a}$ & 6 & $\mathrm{c}$ & 8 & d & 8 & 5 & 8 & 3 & 1 & 1 \\
\hline Glyphosate & 78.76 & 11 & c & 11 & c & 5 & $\mathrm{~d}$ & 12 & 5 & 12 & 2 & 2 & 1 \\
\hline Glyphosate & 157.54 & 33 & $\mathrm{a}$ & 29 & $\mathrm{~b}$ & 29 & bc & 16 & 4 & 13 & 3 & 2 & 1 \\
\hline Imazethapyr $^{\mathrm{d}}$ & 4.39 & 15 & $\mathrm{bc}$ & 16 & c & 14 & $\mathrm{~cd}$ & 11 & 4 & 9 & 3 & 1 & 1 \\
\hline Imazethapyr & 8.74 & 18 & $\mathrm{bc}$ & 29 & $\mathrm{~b}$ & 32 & $\mathrm{~b}$ & 14 & 3 & 9 & 3 & 1 & 1 \\
\hline Imazethapyr & 17.49 & 25 & $a b$ & 93 & $\mathrm{a}$ & 77 & $\mathrm{a}$ & 18 & 8 & 16 & 7 & 3 & 1 \\
\hline
\end{tabular}

${ }^{a}$ Means followed by the same letter are not statistically different according to Fisher's protected LSD $(\alpha=0.05)$.

${ }^{b}$ Timings that did not meet the assumptions of ANOVA are reported as means followed by the standard error of the mean (SE).

${ }^{\mathrm{c}}$ Glyphosate applied as Roundup PowerMax.

${ }^{\mathrm{d}}$ Imazethapyr applied as Newpath.

"Glyphosate rates are in "g ae/ha."

not. This data suggests that year by year the benefits of seed insecticide treatments may be dependent on the overall degree of stress on the rice plants.

The highest rates of both glyphosate and imazethapyr caused the most injury to rice (Table 2). Similar results were previously reported where increasing rates of glyphosate tended to increase rice injury [13]. In 2013, 1 WAT, glyphosate at $157.54 \mathrm{~g}$ ae/ha caused $33 \%$ rice injury and was statistically similar to the injury resulting from imazethapyr at $17.49 \mathrm{~g}$ ai/ha (25\% injury). By 3 and 6 WAT, injury symptoms had become more pronounced from applications of imazethapyr compared to glyphosate with imazethapyr at $17.49 \mathrm{~g}$ ai/ha causing the greatest injury ( 93 and $77 \%$ at 3 and 6 WAT, resp.). To minimize these effects, potential safening from applications of imazethapyr could allow non-Clearfield rice varieties to be planted in close proximity to Clearfield rice with less concern for growers and applicators. In 2014, there was less rice injury compared to 2013. Increasing rates of imazethapyr and glyphosate caused more injury at 1,3 , and 6 WAT. The overall lower level of rice injury observed in 2014 may have been attributed to the later planting date resulting in warmer growing conditions more optimum for rice growth and its ability to recover from the herbicide applications. Likewise, the greater injury observed in 2013 could have been attributed to cool, wet growing conditions thus preventing active growth and its ability to withstand low doses of the herbicide. Nonetheless, the benefit of the insecticide seed treatment in safening rice from low doses of herbicides could be even more beneficial in times when growing conditions are less than optimal.

Significant treatment differences were observed for rice canopy heights near the end of the season, 14 WAT in 2013 (Table 3). As it would be expected, regardless of seed treatment, no difference in height was observed between treatments that did not receive either glyphosate or imazethapyr. However, when glyphosate was applied at $157.54 \mathrm{~g}$ ae/ha, height reductions were apparent in the absence of insecticide seed treatment compared to the case when the seed treatment was applied. Additionally, rice receiving an insecticide seed treatment was able to maintain canopy heights similar to the nontreated control when imazethapyr was applied at rates of 8.74 or $17.49 \mathrm{~g}$ ai/ha, indicating that an insecticide seed treatment can prevent late season rice canopy reduction in the event of an early season exposure to low doses of glyphosate or imazethapyr.

In 2013, both insecticide seed treated and nontreated rice that did not receive a herbicide application exhibited similar heading percentages (91 and 85\% for treated and nontreated rice, resp.) (Table 3). Similar to the results observed for rice canopy height, the addition of an insecticide seed treatment did provide some protection against delayed heading caused by low doses of glyphosate or imazethapyr. In cases where 
TABLE 3: Impact of seed treatment on rice height, percent of heading, and yield following applications of imazethapyr (Newpath) or glyphosate (Roundup PowerMax) in 2013 and 2014.

\begin{tabular}{|c|c|c|c|c|c|c|c|c|c|c|c|c|c|c|}
\hline \multirow{4}{*}{ Insecticide } & \multirow{3}{*}{ Herbicide } & \multirow{3}{*}{$\begin{array}{c}\text { Rate } \\
\text { g ai/ha }{ }^{\mathrm{d}}\end{array}$} & \multicolumn{6}{|c|}{$2013^{\mathrm{a}}$} & \multicolumn{6}{|c|}{$2014^{\mathrm{b}}$} \\
\hline & & & \multicolumn{2}{|c|}{$\begin{array}{l}\text { Height } \\
14 \text { WAT }\end{array}$} & \multicolumn{2}{|c|}{$\begin{array}{c}\text { Heading } \\
14 \text { WAT }\end{array}$} & \multicolumn{2}{|c|}{ Yield } & \multicolumn{2}{|c|}{$\begin{array}{l}\text { Height } \\
14 \text { WAT }\end{array}$} & \multicolumn{2}{|c|}{$\begin{array}{c}\text { Heading } \\
14 \text { WAT }\end{array}$} & \multicolumn{2}{|c|}{ Yield } \\
\hline & & & & & & & \multicolumn{2}{|c|}{$\mathrm{bu} / \mathrm{A}$} & $\mathrm{cm}$ & SE & $\%$ & SE & $\mathrm{bu} / \mathrm{A}$ & SE \\
\hline & None & - & 89 & $\mathrm{a}^{\mathrm{a}}$ & 85 & $a b c$ & 147 & $a b$ & 105 & 1 & 99 & 1 & 207 & 5 \\
\hline \multirow{6}{*}{ Nontreated $^{\mathrm{c}}$} & \multirow{3}{*}{ Glyphosate } & 39.42 & 90 & $\mathrm{a}$ & 58 & de & 104 & $\mathrm{~d}$ & 104 & 1 & 100 & 0 & 199 & 9 \\
\hline & & 78.76 & 82 & a & 68 & $\mathrm{~cd}$ & 113 & $\mathrm{~cd}$ & 104 & 0 & 98 & 1 & 197 & 4 \\
\hline & & 157.54 & 59 & $\mathrm{bc}$ & 28 & fg & 58 & ef & 102 & 1 & 99 & 0 & 194 & 7 \\
\hline & \multirow{3}{*}{ Imazethapyr } & 4.39 & 77 & $a b$ & 45 & ef & 70 & $\mathrm{e}$ & 104 & 1 & 100 & 0 & 197 & 3 \\
\hline & & 8.74 & 54 & c & 23 & $\mathrm{~g}$ & 36 & $\mathrm{fg}$ & 101 & 1 & 100 & 0 & 192 & 4 \\
\hline & & 17.49 & 2 & $\mathrm{~d}$ & 5 & $\mathrm{~h}$ & 17 & $\mathrm{~g}$ & 97 & 1 & 99 & 1 & 182 & 7 \\
\hline \multirow{7}{*}{ Treated } & None & - & 90 & $\mathrm{a}$ & 91 & $\mathrm{a}$ & 169 & $\mathrm{a}$ & 107 & 1 & 99 & 0 & 217 & 7 \\
\hline & \multirow{3}{*}{ Glyphosate } & 39.42 & 97 & a & 79 & $a b c$ & 148 & $\mathrm{ab}$ & 104 & 1 & 97 & 2 & 198 & 5 \\
\hline & & 78.76 & 90 & a & 73 & bcd & 144 & $\mathrm{ab}$ & 109 & 0 & 97 & 1 & 197 & 7 \\
\hline & & 157.54 & 88 & a & 73 & bcd & 128 & bcd & 104 & 1 & 100 & 0 & 195 & 7 \\
\hline & \multirow{3}{*}{ Imazethapyr } & 4.39 & 93 & a & 86 & $a b$ & 170 & $\mathrm{a}$ & 104 & 1 & 100 & 0 & 198 & 3 \\
\hline & & 8.74 & 84 & a & 68 & $\mathrm{~cd}$ & 136 & $\mathrm{bc}$ & 107 & 1 & 98 & 1 & 198 & 1 \\
\hline & & 17.49 & 76 & $a b$ & 14 & gh & 45 & ef & 104 & 1 & 99 & 0 & 190 & 4 \\
\hline
\end{tabular}

${ }^{\mathrm{a}}$ Means followed by the same letter are not statistically different according to Fisher's protected LSD $(\alpha=0.05)$.

${ }^{b}$ Timings that did not meet the assumptions of ANOVA are reported as means followed by the standard error of the mean (SE).

“"Nontreated" means the rice seed received fungicide only and no insecticide seed treatment whereas "treated" means the rice seed was treated with $198 \mathrm{~g} / 45 \mathrm{~kg}$ of CruiserMaxx Rice.

dGlyphosate rates are in "g ae/ha."

insecticide seed treated rice was also treated with glyphosate at $39.42,78.76$, or $157.54 \mathrm{~g}$ ae/ha, percent of heading was similar to the herbicide/insecticide control. However, the same effect for imazethapyr was only observed when rice was exposed to the lowest rates used in this experiment. In 2014, all treatments had 97 to $100 \%$ heading by 14 WAT.

Rice grain was harvested for the entire test when plots not treated with herbicide reached maturity. Rough rice grain yields for each treatment were adjusted to 20\% moisture at the time of harvest. For the purposes of this study, a single harvest date was chosen to simulate a grower decision of when to harvest a rice field which contained varying degrees of damage. Therefore, at the time of harvest, plots which exhibited the most severe rice injury and reductions in canopy heights and percent of heading likewise resulted in the lowest yield. Yields in 2014 were overall higher than those in 2013 likely due to the increased growth resulting from warmer growing conditions. However, no differences among treatments existed. Conversely, in 2013, the addition of an insecticide seed treatment did provide some safening from glyphosate and imazethapyr with regard to its ability to maintain yield similar to plots not treated with a herbicide (Table 3). Likewise, the largest yield reductions were observed when the highest rates of glyphosate and imazethapyr were applied. With the addition of an insecticide seed treatment, yield increased significantly, as seen in other crops [10, 11]. Moreover, and in general terms, regardless of the seed treatment applied, yield tended to increase as application rate of either herbicide decreased.

\section{Conclusions}

The benefits of an insecticide seed treatment in rice have been well documented [14]. In work conducted over a 5year period from 2007 to 2013, with multiple studies, it was determined that several different insecticide seed treatments resulted in positive net returns from 70 to $80 \%$ of the time, whether or not a specific insect pest was present. The ability of an insecticide seed treatment to reduce injury to rice from exposure to low doses of glyphosate and imazethapyr could be an additional benefit to growers by reducing yield losses. Although the safening response observed in 2014 was not as great as what was seen in 2013, the utilization of seed treatments will likely reduce rice injury and prevent delayed heading while protecting grain yield potential in situations where rice is exposed to low doses of the herbicides glyphosate or imazethapyr. Therefore, we fail to reject our hypothesis that an insecticide seed treatment in rice will be able to provide some safening effect from low doses of herbicides. This is a benefit not only to growers but also to extension personnel, industry representatives, and applicators alike by reducing the risk associated with misapplication in turn decreasing the number of complaints resulting from injurious exposure. Furthermore, the results herein confirm previous reports of insecticide seed treatments providing a safening effect from herbicide applications $[11,12,15,16]$. This research aims to serve as a starting point in the understanding of the herbicide safening effect an insecticide seed treatment may provide in rice. Further research should be performed 
to evaluate the safening potential of other insecticide seed treatments on rice from low doses of other commonly applied herbicides that cause substantial crop injury. Future studies should also evaluate the potential for this safening effect in other commonly produced row crops.

\section{Competing Interests}

The authors declare that they have no competing interests.

\section{Acknowledgments}

Support for this research was provided by the rice growers of Arkansas, administered by the Arkansas Rice Research and Promotion Board, and is greatly appreciated.

\section{References}

[1] [USDA NASS] United States Division of Agriculture, National Agriculture Statistics Service, 2015, http://www.nass.usda.gov.

[2] J. T. Hardke, Trends in Arkansas Rice Production, 2014, B.R. Wells Rice Research Studies, 2015.

[3] J. T. Hardke and C. E. Wilson Jr., "Trends in Arkansas rice production," in B.R. Wells Rice Research Studies 2012, R. J. Norman and K. A. K. Moldenhauer, Eds., pp. 38-47, Arkansas Agricultural Experiment Station, Fayetteville, Ark, USA, 2013.

[4] C. E. Wilson, S. K. Runsick, and R. Mazzanti, Trends in Arkansas Rice Production, B.R. Wells Rice Research Studies 2009, 2010.

[5] B. M. Davis, R. C. Scott, J. K. Norsworthy, and E. Gbur, "Response of rice (Oryza sativa) to low rates of glyphosate and glufosinate," Weed Technology, vol. 25, no. 2, pp. 198-203, 2011.

[6] J. B. Hensley, E. P. Webster, D. C. Blouin, D. L. Harrell, and J. A. Bond, "Impact of drift rates of imazethapyr and low carrier volume on non-clearfield rice," Weed Technology, vol. 26, no. 2, pp. 236-242, 2012.

[7] J. B. Hensley, E. P. Webster, D. C. Blouin, D. L. Harrell, and J. A. Bond, "Response of rice to drift rates of glyphosate applied at low carrier volumes," Weed Technology, vol. 27, no. 2, pp. 257262, 2013.

[8] M. R. Douglas and J. F. Tooker, "Large-scale deployment of seed treatments has driven rapid increase in use of neonicotinoid insecticides and preemptive pest management in U.S. field crops," Environmental Science and Technology, vol. 49, no. 8, pp. 5088-5097, 2015.

[9] C. C. Bowling and H. R. Hudgins, "The effect of insecticides on the selectivity of propanil on rice," Weeds, vol. 14, no. 1, pp. 9495, 1966.

[10] J. Hacskaylo, J. K. Walker Jr., and E. G. Pires, "Response of cotton seedlings to combinations of preemergence herbicides and systemic insecticides," Weeds, vol. 12, no. 4, pp. 288-291, 1964.

[11] A. C. York, D. L. Jordan, and R. E. Frans, "Insecticides modify cotton (Gossypium hirsutum) response to clomazone," Weed Technology, vol. 5, no. 4, pp. 729-735, 1991.

[12] A. C. York and D. L. Jordan, Weed Technol, Cotton response to clomazone and insecticide combinations. Weed Technol, 796800, 1992.

[13] J. M. Ellis, J. L. Griffin, S. D. Linscombe, and E. P. Webster, "Rice (Oryza sativa) and corn (Zea mays) response to simulated drift of glyphosate and glufosinate," Weed Technology, vol. 17, no. 3, pp. 452-460, 2003.
[14] N. M. Taillon, G. M. Lorenz W, M. E. Everett et al., "A historical look at rice insecticide seed treatments from," B.R. Wells Rice Research Studies, pp. 174-181, 2013.

[15] W. A. Plummer, G. M. Lorenz, N. M. Taillon, B. C. Thrash, J. W. Fortner, and C. K. Colwell, "Impact of insecticide seed treatments in large block field trials in Arkansas 2009-2011," in B.R. Wells Rice Research Studies 2011, pp. 128-132, University of Arkansas, 2012.

[16] H. Wilf, G. M. Lorenz, K. Colwell, and N. Taillon, Comparing the Efficacy of Insecticide Seed Treatments at Three Seeding Rates, B.R. Wels Rice Research Studies 2009, 2010. 


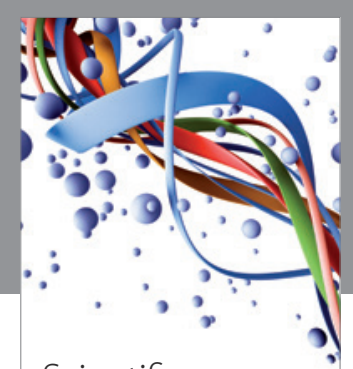

Scientifica
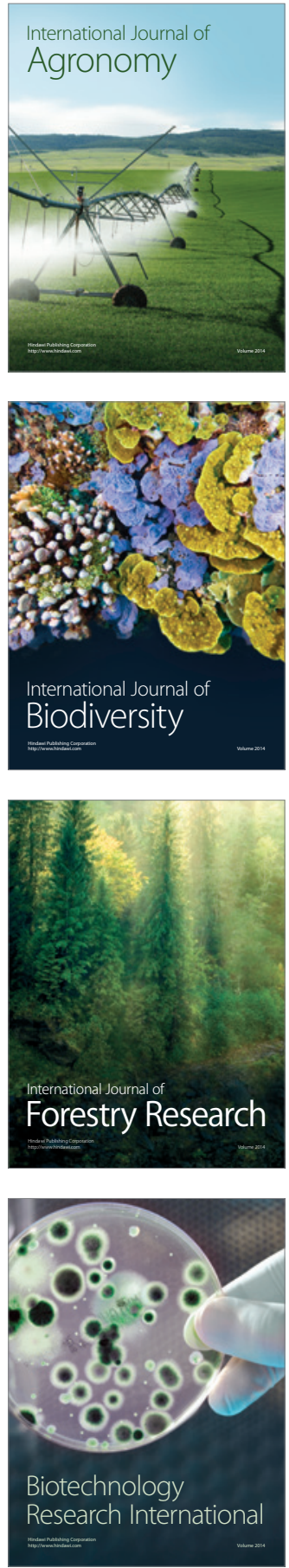
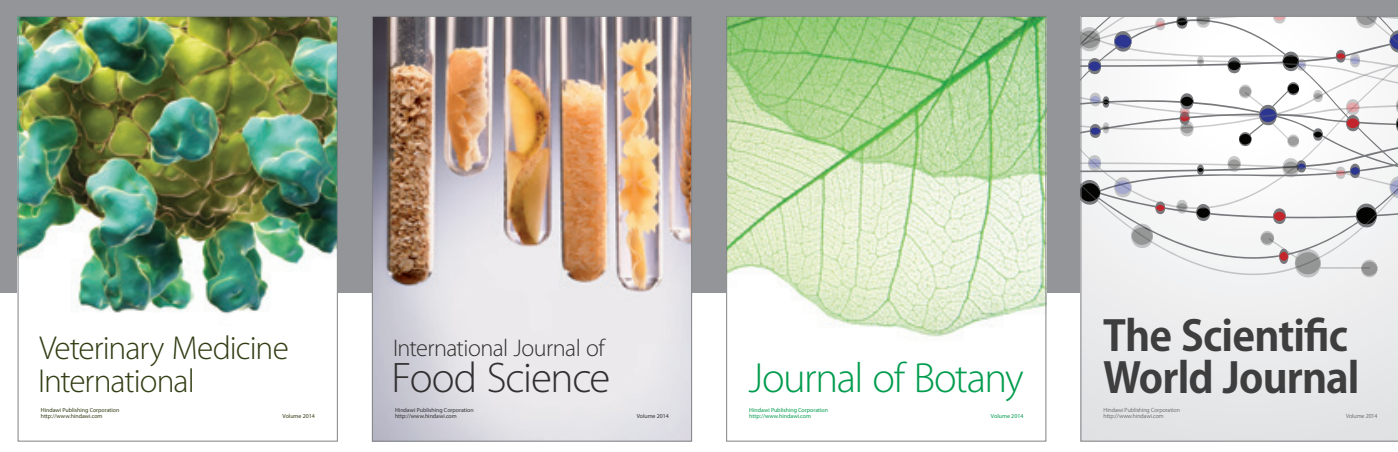

The Scientific

\section{World Journal}

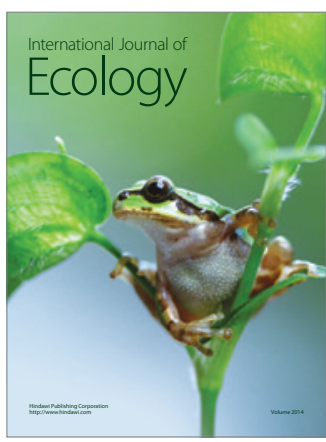

\section{Hindawi}

Submit your manuscripts at

http://www.hindawi.com
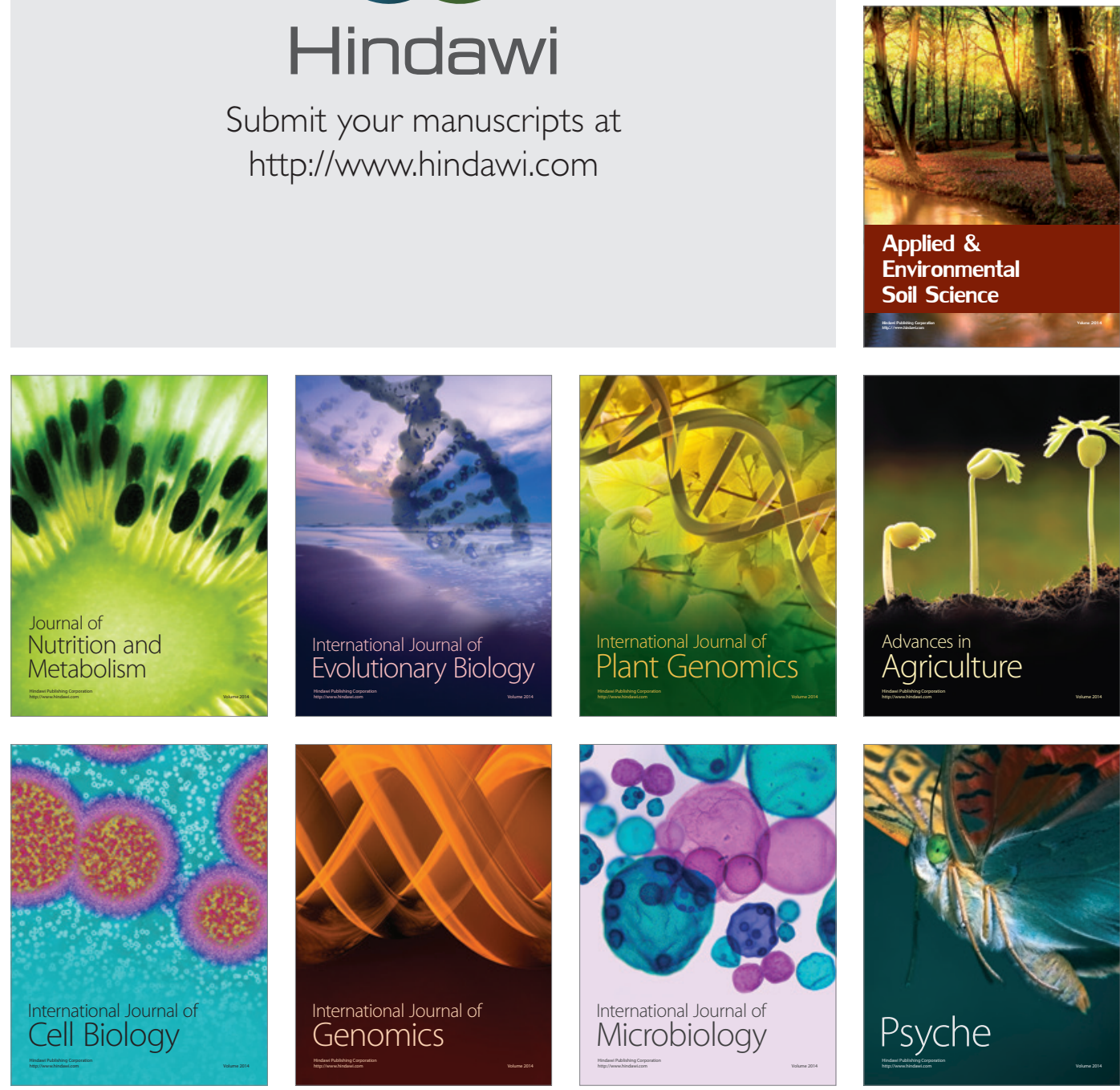
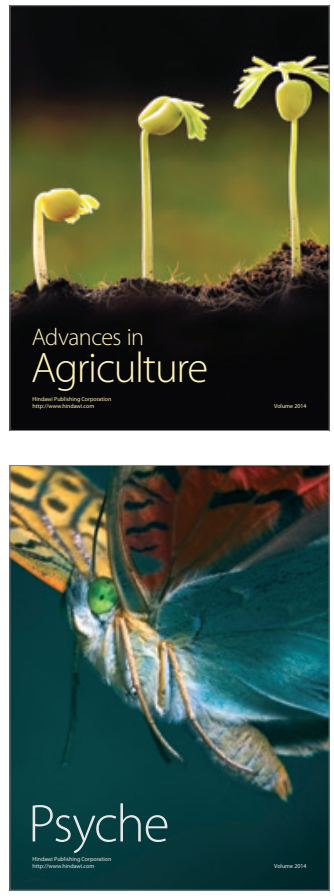